\title{
OPEN ADULT FEMORAL SHAFT FRACTURE TREATED BY EARLY INTRAMEDULLARY NAILING
}

\author{
A. GROSSE, J. CHRISTIE, G. TAGLANG, C. COURT-BROWN, M. MCQUEEN
}

From Princess Margaret Rose Orthopaedic Hospital, Edinburgh, Scotland

In two hospitals, 115 consecutive open femoral shaft fractures were treated by meticulous wound excision and early locked (97) or unlocked (18) intramedullary nailing. All the fractures united; union was delayed in four, three of which required bone grafting. The average range of knee fiexion at follow-up was $134^{\circ}(60$ to 148$)$. Five patients had a final range of less than $120^{\circ}$, but three of these improved after manipulation under general anaesthesia. Three patients developed staphylococcal infections and required further surgical treatment. All eventually healed.

J Bone Joint Surg [Br] 1993; 75-B:562-5.

Received 13 January 1993; Accepted 3 March 1993

Friedrich, in 1898, showed experimentally that excision of open wounds substantially reduced the risk of infection. His techniques were extensively applied during the First World War allowing Böhler (1935) to report remarkable survival and infection figures (98\% survival of life and limb) using traction to immobilise the injured femur. In 1922 Hey Groves was the first surgeon to use massive intramedullary nails to stabilise open femoral fractures but he concluded, as did Smith in 1964, that the risk of infection was too great to allow routine use of the method. Küntscher (1967), however, nailed open fractures of the femur regularly and Winquist, Hansen and Clawson (1984), mainly using Küntscher's technique, reported a low infection rate in a series of 42 open femoral fractures treated by primary intramedullary fixation. Lhowe and Hansen updated this series in 1988 and more recently Brumback et al (1990) reported only three infections in a series of 89 open fractures treated by early nailing. Since 1984 immediate or early intramedullary nailing has been used in Strasbourg and in Edinburgh and we report our

A. Grosse, Head of Spinal Unit

J. Christie, FRCS, Consultant Orthopaedic Surgeon

G. Taglang, Head of Emergency Department

C. Court-Brown, MD, FRCS Ed(Orth), Consultant Orthopaedic Surgeon

M. McQueen, FRCS Ed(Orth), Senior Lecturer in Orthopaedic Surgery Princess Margaret Rose Orthopaedic Hospital, Fairmilehead, Edinburgh EH10 7ED, UK.

Correspondence should be sent to Mr J. Christie.

(C)1993 British Editorial Society of Bone and Joint Surgery

$0301-620 X / 93 / 4620 \$ 2.00$ results in 115 consecutive open femoral fractures treated by the locking nail system of Kempf, Grosse and Lafforgue (1978).

\section{PATIENTS AND METHODS}

All patients with open femoral shaft fractures admitted between January 1984 and July 1990 to the Centre for Traumatology, Strasbourg or to the Royal Infirmary, Edinburgh were treated by meticulous wound care followed by intramedullary nailing, provided that the fracture configuration was suited to that form of fixation. The patients were registered prospectively in each centre, and each patient's visit was recorded on the database. Patients who failed to attend the clinics were questioned by telephone or contacted by post.

There were 111 patients with 115 open femoral fractures with adequate follow-up for inclusion in the study (65 patients with 66 fractures in Strasbourg; 46 with 49 fractures in Edinburgh). Those patients who died within two months of the intramedullary nailing were excluded. Two patients died from unrelated causes during the follow-up period and four could be contacted only by telephone or by post. Six patients had incomplete followup data although the final outcome was known in them all.

There were 96 men and 15 women in the series. The average age of the men was 25 years ( 15 to 68), and of the women 32 years (15 to 82). In 97 of the patients the injuries had been caused by road-traffic accidents, in six by falls, in five by industrial or work-related crush accidents, and in three by gunshot wounds. Only 17 of the 111 patients had single injuries. Table I records the other injuries sustained by the patients.

The injury severity scores for the 46 patients treated in Edinburgh are given in Table II. They were not recorded in Strasbourg.

Operative technique. Patients with open femoral fractures often have multiple injuries and require resuscitation, ventilatory support, intensive or high-dependency care and multiple surgical procedures. In the emergency room the open femoral fractures were cleaned and covered with a sterile dressing. A temporary splint was applied to stabilise the leg. The definitive surgery was undertaken at the earliest opportunity, most patients having the femur nailed within a few hours of injury and during the 
same anaesthetic as other essential surgical procedures. One hundred and six fractures were nailed on the day of injury and nine were delayed for up to ten days. The commonest cause for delay was a bleeding diathesis in the early period after injury which required haematological treatment.

The wound was meticulously excised and washed out, a traction pin was passed through the distal femur and the patient was placed on a traction table. The nailing procedure took an average of 93 minutes (40 to 220 ) and required a mean 2.8 minutes $(0.1$ to 8$)$ of irradiation time; the latter was substantially longer in the Strasbourg series ( 3 minutes) than in the Edinburgh series (28 seconds). Seventy-one femurs were fixed with cross-bolts both proximally and distally (static lock), 26 with a cross-bolt at one or other end (dynamic lock) and 18 were not locked. Twenty-nine patients subsequently underwent dynamisation by removal of one of the crossscrews ( 28 in Strasbourg, one in Edinburgh) before union occurred. Table III gives the nail sizes and diameters. There were no implant or screw fractures in the series.

The wound was left open and dressed with a sterile pack. Re-exploration and re-excision were undertaken within 48 hours if necessary and early skin cover or closure was planned. No rotation or free flaps were required and split skin graft was applied within six days. All patients were given third-generation cephalosporins intravenously for at least three days, and for longer if the wound was extensive and badly contaminated.

Rehabilitation varied with the severity of the femoral injury but mobilisation of the knee by continuing passive motion was started, whenever possible, in the immediate postoperative period. Weight-bearing was delayed for six weeks or more in patients with comminuted fractures. Fracture comminution. Fracture comminution was classified according to the system of Winquist et al 1984 and the details are given in Table IV. Eight patients had ipsilateral femoral neck fractures and one of these had three fractures at separate levels in the same femur. One of the femoral neck fractures was not evident on the preoperative radiographs and was probably caused by the operative procedure.

Classification of the open fractures. There were 36 grade I fractures (Gustilo, Mendoza and Williams 1984), 42 grade II, and 37 grade III. Five of the grade III fractures had associated vascular injuries and were classified as grade IIIc. Of the remaining 32 fractures, 20 were thought to be grade IIIa and 12 grade IIIb. We believe that the system of classification has been applied somewhat stringently, particularly in Strasbourg, and that the number of IIIb fractures may have been underestimated.

\section{RESULTS}

The patients were in hospital for an average of 4.2 weeks (10 to 56 days); partial weight-bearing started after an average of 6.4 weeks ( 3 to 270 days). The prolonged delay
Table I. Associated injuries sustained by 111 patients with open femoral shaft fractures

\begin{tabular}{ll}
\hline Associated injuries & Number \\
\hline Head & 54 \\
Chest & 24 \\
Abdomen & 11 \\
Pelvis & 19 \\
Spine & 4 \\
Vascular & 5 \\
Upper limb & 45 \\
Contralateral lower limb & 54 \\
\hline
\end{tabular}

Table II. Injury severity score (ISS) of the 46 patients treated in Edinburgh for open fractures of the femoral shaft

\begin{tabular}{ll}
\hline $\begin{array}{l}\text { ISS } \\
\text { (points) }\end{array}$ & $\begin{array}{l}\text { Number of } \\
\text { patients }\end{array}$ \\
\hline 16 to 19 & 26 \\
20 to 29 & 14 \\
30 to 39 & 2 \\
40 to 49 & 3 \\
50 to 59 & 1 \\
\hline
\end{tabular}

Table III. Diameters and lengths of 101 intramedullary nails (data for 14 nails were not recorded)

\begin{tabular}{lccc}
\hline $\begin{array}{l}\text { Diameter } \\
(\mathbf{m m})\end{array}$ & Number & $\begin{array}{l}\text { Length } \\
(\mathrm{mm})\end{array}$ & Number \\
\hline 11 & 4 & 46 & 3 \\
12 & 46 & 48 & 3 \\
13 & 35 & 44 & 13 \\
14 & 11 & 42 & 25 \\
15 & 3 & 40 & 37 \\
16 & 2 & 38 & 16 \\
& & 36 & 4 \\
\hline
\end{tabular}

Table IV. Degree of comminution of the 115 fractures according to the classification of Winquist et al (1984)

\begin{tabular}{ll}
\hline Type of fracture & $\begin{array}{l}\text { Number of } \\
\text { patients }\end{array}$ \\
\hline Simple uncomminuted & 23 \\
$<50 \%$ contact & 29 \\
$>50 \%$ contact & 34 \\
Comminuted & 24 \\
Segmental & 5 \\
\hline
\end{tabular}




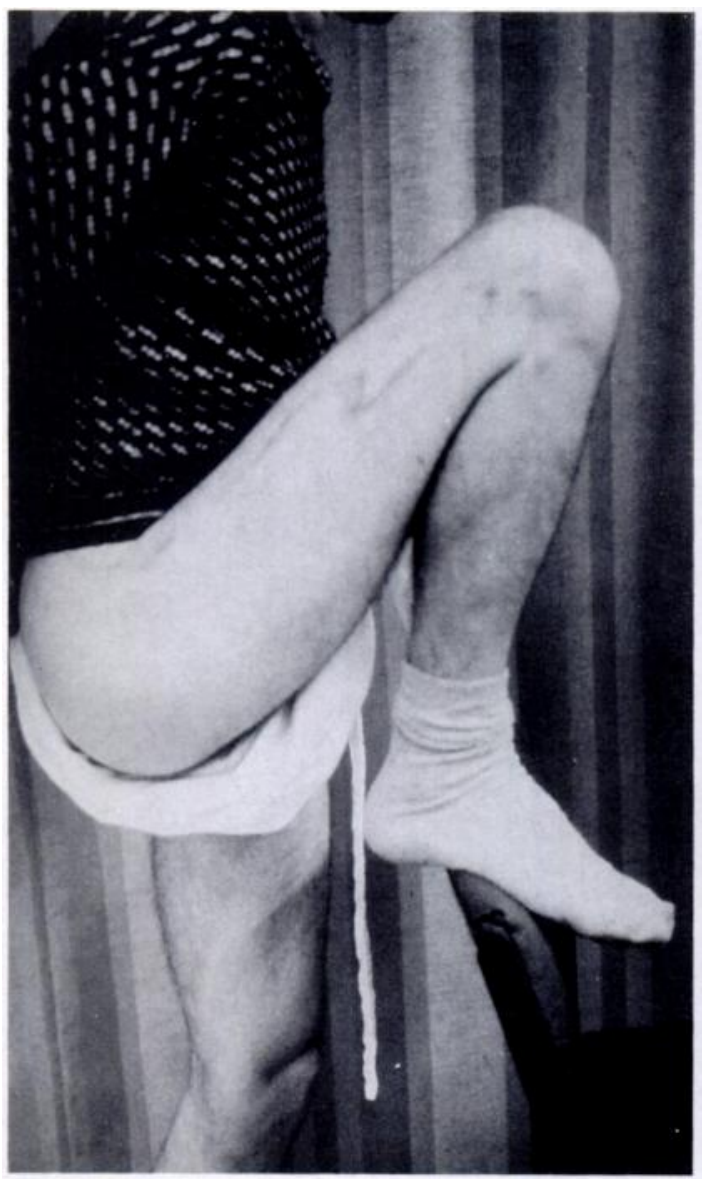

Fig. 1a

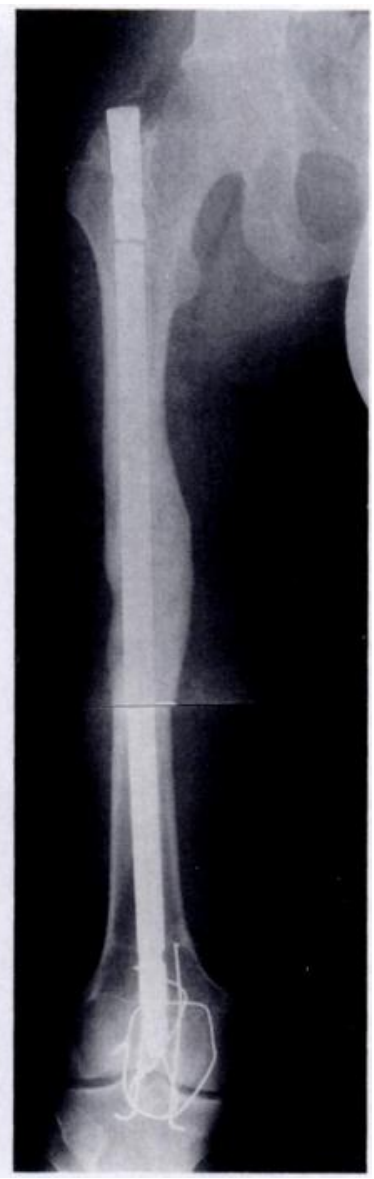

Fig. 1b
The end result in a patient who developed infection six weeks after early nailing of his open femoral fracture. Sequestrectomy and exchange nailing were performed, resulting in union of the fracture and eradication of the infection. (Nail breakage occurred after the fracture had united.) was caused by the large number of patients who had complex or comminuted fractures. Full weight-bearing without aid was achieved at an average of 92 days (8 to 300 ) and those patients who returned to work did so at an average of 148 days (60 to 270 ). One year after injury 29 patients had failed to return to their previous work; in about half this was attributable to injuries other than the femoral fracture.

Union. Union occurred in all patients at an average time of 156 days ( 84 to 252). In four it was delayed, in one due to infection. Two of these patients required renailing and grafting, one grafting alone, and one responded to dynamisation.

Joint movement. No stiffness was noted in the hips. Ankle and subtalar movements were not measured.

The average range of knee movement was $135^{\circ}(60$ to 148). All but three patients achieved a flexion range better than $120^{\circ}$. One patient with severe soft-tissue injuries had a flexion range of only $60^{\circ}$. Another had only $115^{\circ}$ flexion after very severe soft-tissue injuries and fractures involving the femoral condyles. One other patient died of carcinomatosis at three months after injury with a recorded range of $115^{\circ}$ flexion; we have no reason to believe that there would have been any restriction of knee motion in this patient. Three patients underwent manipulation for severe knee stiffness and eventually achieved ranges of movement better than $120^{\circ}$.

Infection. Three patients developed serious infections. Two were treated by early excision of all pyogenic membrane, rereaming of the femur, exploration of the fracture site and removal of dead bone, and renailing. One of these subsequently required bone grafting (Fig. 1). The third patient developed a small sinus which healed after removing the nail. In all three there is no evidence of recurrence of infection.

Neurological complications. There were two transient sciatic nerve palsies in the postoperative period. Three common peroneal nerve injuries caused at the time of accident have not recovered.

Haematomas. There were five significant wound haematomas which resolved without intervention.

Leg shortening. Ten patients had some shortening. The most severe was a leg-length discrepancy of $1.5 \mathrm{~cm}$ in a patient whose intramedullary nail was not statically locked. In two patients shortening was $10 \mathrm{~mm}$ or more and in six $5 \mathrm{~mm}$ or more. In four patients it occurred despite the use of statically locked nails.

Femoral neck fracture. One femoral neck fracture was attributed to the operative procedure. Seven others had occurred at the time of the initial violence. All were treated by cancellous screw fixation after nailing of the 
open femoral shaft fracture, the screws passing up the femoral neck in front of or behind the nail. All these fractures healed.

Perineal oedema. One patient developed vulval oedema because of excessive traction on the injured leg during the operation.

Deaths. Two patients died of unrelated causes during follow-up: one had carcinomatosis and one successfully committed suicide by jumping a second time.

\section{DISCUSSION}

The results in our series of open femoral fractures treated by immediate or early intramedullary nailing confirm the findings of Winquist et al (1984), Lhowe and Hansen (1988), and Brumback et al (1990) that the method has a low overall complication rate and a remarkably low infection rate. The series reported by Brumback et al, like our own, consisted mainly of patients injured in road-traffic accidents and therefore subjected to highenergy transfer at the time of injury, often with serious soft-tissue damage and contamination.

These injuries are very different from gunshot injuries and may therefore be expected to behave in a different way. Some civilian authors (Pankovich, Goldflies and Pearson 1979; Wiss, Brien and Becker 1991) have recommended early intramedullary fixation for lowvelocity gunshot wounds and some have suggested that formal excision of the bullet track is unnecessary. Military opinion, however, is against early internal fixation possibly because of the prevalence of multiple highvelocity fragment tracks in wounds sustained in battle.

There were relatively few IIIc and IIIb fractures in our series, but enough to suggest that meticulous excision followed by intramedullary fixation is appropriate for these serious fractures.

Early intramedullary fixation is a safe and efficient method of treating open femoral shaft fractures in civilian practice.

Although none of the authors have received or will receive benefits for personal or professional use from a commercial party related directly or indirectly to the subject of this article, benefits have been or will be received but are directed solely to a research fund, foundation, educational institution, or other non-profit institution with which one or more of the authors is associated.

\section{REFERENCES}

Böhler L. Translated by Hey Groves EW. The treatment of fractures. 4th English ed, translated from 4th German ed. Bristol: John Wright \& Sons Ltd. London: Simpkin Marshall Ltd, 1935.

Brumback RJ, Wells JD, Lakatos R, et al. Heterotopic ossification about the hip after intermedullary nailing for fractures of the femur. J Bone Joint Surg [Am] 1990; 72-A :1067-73.

Friedrich PL. Die aseptische Versorgung frischer Wunden unter Mittheilung von Thier-Versuchen uber die Auskeimungszeit von Infectionserregern in frischen Wunden. Arch Klin Chir 1898: 287-310.

Gustilo RB, Mendoza RM, Williams DN. Problems in the management of type III (severe) open fractures: a new classification of type III open fractures. $J$ Trauma $1984 ; 24: 742-6$.

Hey Groves EW. On modern methods of treating fractures including the Jacksonian prize essay on bone grafting. 2nd ed. Bristol: John Wright and New York: William Wood \& Company, 1922.

Kempf I, Grosse A, Lafiorgue D. L'apport due verrouillage dans l'enclouage centro-médullaire des os longs. Rev Chir Orthop 1978; $64: 635-51$.

Küntscher G. Translated by Rinne HH. Practice of intramedullary nailing. Springfield, Illinois: Charles C Thomas, 1967.

Lhowe DW, Hansen ST. Immediate nailing of open fractures of the femoral shaft. J Bone Joint Surg [Am] 1988; 70-A :812-20.

Pankovich AM, Goldflies ML, Pearson RL. Closed Ender nailing of femoral-shaft fractures. J Bone Joint Surg [Am] 1979; 61-A: 222-32.

Smith JEM. The results of early and delayed internal fixation of fractures of the shaft of the femur. J Bone Joint Surg [Br] 1964; 46-B :28-31.

Winquist RA, Hansen ST Jr, Clawson DK. Closed intramedullary nailing of femoral fractures: a report of five hundred and twenty cases. J Bone Joint Surg [ Am] 1984; 66-A :529-39.

Wiss DA, Brien WW, Becker V. Interlocking nailing for the treatment of femoral fractures due to gunshot wounds. J Bone Joint Surg [Am] 1991; 73-A:598-606. 